\title{
Description of Paratylenchus (Gracilacus) straeleni (De Coninck, 1931) Oostenbrink, 1960 (Nematoda: Criconematoidea, Tylenchulidae) from hazelnut in Turkey and its comparison with other world populations
}

\author{
F. AKYAZI' , A. F. FELEK ${ }^{2}$, V. ČERMÁK ${ }^{3,5, *}$, M. ČUDEJKOVÁ4 , J. FOIT ${ }^{5}$, S. YILDIZ ${ }^{6}$, L. HÁNĚL' ${ }^{7}$
}

\begin{abstract}
'Department of Plant Protection, Agricultural Faculty, University of Ordu, 52200, Turkey; ${ }^{2}$ Department of Horticulture, Agricultural Faculty, University of Ordu, 52200, Turkey; ${ }^{3}$ Department of Forest Protection and Wildlife Management, Faculty of Forestry and Wood

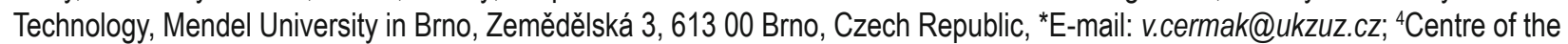
Region Haná for Biotechnological and Agricultural Research, Department of Molecular Biology,Šlechtitelu 586/11, 779 00 Olomouc,

Czech Republic; ${ }^{5}$ Central Institute for Supervising and Testing in Agriculture, Division of diagnostics, Šlechtitelů 23/773, 77900

Olomouc, Czech Republic; ${ }^{6}$ Plant Protection Department of, Agricultural Faculty, University of Bingöl, 12000, Turkey; ${ }^{7}$ nstitute of Soil Biology, Biology Centre, The Czech Academy of Sciences, Na Sádkách 7, 37005 České Budèjovice, Czech Republic
\end{abstract}

\begin{abstract}
Article info
Received February 10, 2015 Accepted April 9, 2015
\end{abstract}

\begin{abstract}
Summary
Paratylenchus (Gracilacus) straeleni (De Coninck, 1931) Oostenbrink, 1960 was detected for the first time in Turkey. Our studied population was found in the rhizosphere soil of hazelnut orchards in Ordu. Females and males were studied morphologically and morphometrically by light microscopy and molecularly by sequencing the D2-D3 of the 28S rDNA gene. We present here the morphological and molecular characterisation, phylogenetic analysis of examined population and comparison of variability of worldwide known populations of $P$. straeleni.
\end{abstract}

Keywords: Corylus avellana; Multivariate analyses; Phylogeny; Sequencing; Species complex

\section{Introduction}

Hazelnut (Corylus avellana L.) is a main perennial crop in Turkey and the country is first-ranked in worldwide hazelnut production and exportation (Akyazi et al. 2014). Ordu is the top province among the provinces producing hazelnut in Turkey but nematode fauna in hazelnut orchards is only partially known. Kepenekci (2002) reported plant parasitic species from the soil and root samples of hazelnut in the West Black Sea region of Turkey without finding any species of the genus Paratylenchus. Akyazi et al. (2014) surveyed 110 hazelnut orchards for nematode assemblages and found representatives of both subgenera, Paratylenchus and Gracilacus.

Paratylenchus straeleni was described from moss and soil from Baraque Michel, Liége, Belgium. The type and neotype descriptions were based upon two and one females respectively (De Coninck, 1931; Geraert, 1965). However P. straeleni is a species spread worldwide known from North America (Raski, 1962, Van den Berg et al., 2014), Africa (Van den Berg \& Tiedt, 2001), Europe (De Coninck, 1931; Brzeski \& Háněl, 2000), Asia (Eroshenko, 1974; Ghaderi et al., 2014) and New Zealand (Raski, 1976) (Fig. 1). The long-stylet species of the genus Paratylenchus are in general considered to be root parasites of trees and shrubs (Raski, 1962; Van den Berg et al., 2014) but some, such as $P$. steineri Golden, 1961, can feed on meadow plants (Brzeski \& Háněl, 1999). In temperate Europe, $P$. straeleni mostly occur in more or less natural habitats (Sturhan, 2014). In Mediterranean perennial-crop agroecosystems, $P$. straeleni was for the first time reported in association with hazelnut (Corylus avellana L.) from the soil around hazelnut roots in northern Greece. The abundance was high at approximately 100 specimens per $200 \mathrm{~g}$ of soil, the plant showed discoloration of the leaves and retarded growth (Kyrou, 1976). Mancini et al. (1975) reported infestation by Gracilacus audriellus (Brown, 1959) Raski, 1962 in Italy.

Paratylenchus straeleni, as with many other species of this genus, shows high levels of intraspecific variability in many morphometrical and morphological characteristics and can be considered a complex of cryptic species. The highly variable tail length and shape, rations $c$ and $c$ ' were concluded to be unreliable for separation of closely related species (Brzesky \& Háněl, 2000). Nevertheless, the broad and overlapping ranges of some characteristics and intraspecific variability can be distinctly different in isolated populations. It led to the description of three closely related species Paratylenchus audriellus Brown, 1959 with claw-like tail tip, 


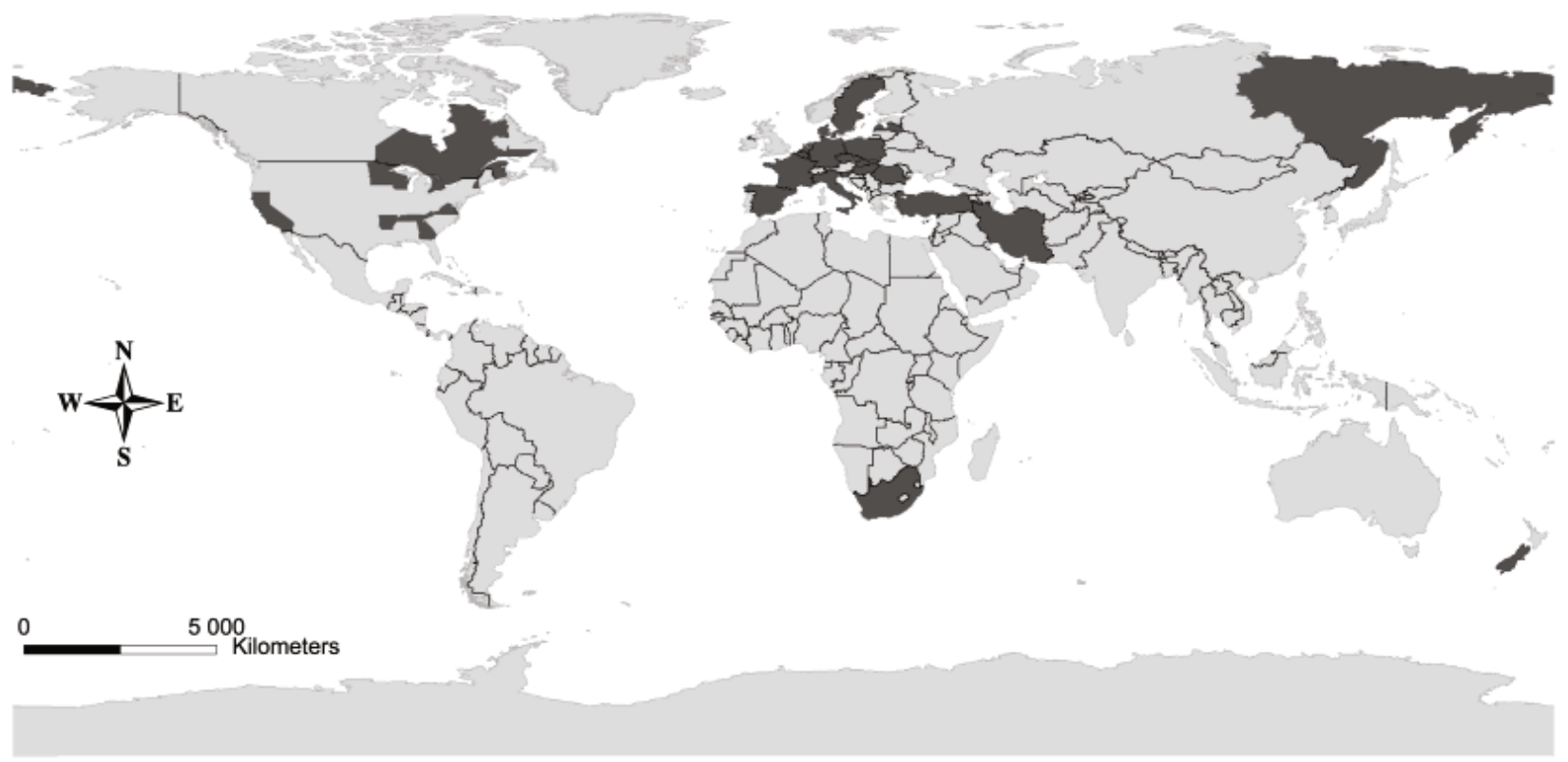

Fig. 1. Map of world distribution of Paratylenchus (Gracilacus) straeleni

Paratylenchus sarissus Tarjan, 1960 with pointed to finely rounded tail tip and Paratylenchus abietis Eroshenko, 1974 with mostly pointed tail tip, but with swelled posterior half of pharynx corpus and missing labial annules that were present in the two species described earlier. Later on, the three species were synonymized with Gracilacus (or Paratylenchus) straeleni (Raski, 1976; Brzeski, 1998). The identity of Paratylenchus straeleni was unclear until Geraert (1965) described neotype. Hemicycliophora (Procriconema) strenzkei Volz, 1951 remains problematic, nevertheless the specimens described probably also belonged to Paratylenchus straeleni. More information on the issue with spelling corrections can be found in Raski (1976), Siddiqi (2000), Andrássy (2007) and Ghaderi et al. (2014); see also Appendix 1. on complicated position of Paratylenchus straeleni s.l. in Paratylenchus s.l. In the text on we use names of individual species as published in papers we refer to. Nevertheless in the title we follow Siddiqi (2000) who regarded Gracilacus as a subgenus of Paratylenchus.

The aims of our study were (i) to characterize the population of $P$. straeleni found in hazelnut rhizosphere in Turkey, (ii) to provide multivariate analysis of biometrical data from various populations of $P$. straeleni collected world-wide, (iii) to perform sequencing of the $28 \mathrm{~S}$ rDNA loci in the Turkey population and align the obtained sequences with those already known from other populations.

\section{Material and Methods}

Samples were collected in September $2013\left(40^{\circ} 46^{\prime} 02.65^{\prime \prime} \mathrm{N}\right.$; $\left.37^{\circ} 27^{\prime} 18.19^{\prime \prime} \mathrm{E}\right)$ from the rhizosphere of hazelnut in hazelnuts orchard in Ordu as a part of general survey for nematofauna associated with hazelnuts grown in Black Sea region of Turkey.

Soil samples were taken from the rhizosphere of the hazelnut trees at $5-30 \mathrm{~cm}$ depth. The nematodes were extracted from 50 $\mathrm{g}$ of soil by Cobb's sieving and decanting method (Cobb, 1918). Extracted nematodes were partially killed and fixed in $4 \%$ formalin and transferred to pure glycerine according to De Grisse (1969) and partially used for DNA extraction. Using a light microscope (Leica, DMLB), morphological and morphometric analyses were performed. Nematode identification was based on observations of the main morphological features for the genus Paratylenchus particularly head, tail and spermatheca shape, presence of males and contents of sperm in spermatheca, number of incisures in the lateral field, stylet and stylet cone length, position of vulva, and presence of advulval flaps (Brzeski \& Háněl 2000; Ghaderi et al. 2014).

Nematode morphological identification was confirmed by molecular analyses (sequencing of the 28S rDNA loci). DNA was extracted as follows: three specimens were collected into $10 \mu$ of extraction buffer (10 mM Tris-HCl, pH 8.8; 1 mM EDTA; 1 \% Triton X-100 $(\mathrm{v} / \mathrm{v}) ; 100 \mu \mathrm{g} / \mathrm{ml}$ Proteinase $\mathrm{K})$ in a $1.5 \mathrm{ml}$ Eppendorf tube. Each sample was ground using a micropestle and incubated at $55^{\circ} \mathrm{C}$ for $1 \mathrm{~h}$ and subsequently at $95^{\circ} \mathrm{C}$ for $10 \mathrm{~min}$. The mixture was used as a DNA template for PCR. The LSU region of rDNA was amplified using a Phusion High Fidelity DNA polymerase (having $3 \_\rightarrow 5$ exonuclease activity) (NEB). GoTaq DNA polymerase (Promega) was added to a terminal $10 \mathrm{~min} / 72^{\circ} \mathrm{C}$ elongation step to create a poly A overhang for subsequent TA cloning. The primers used for the amplification of the the 28S rDNA (D2D3 region of the large subunit, LSU) were: D2A (5'-ACA AGT ACC GTG AGG GAAAGT TG-3') and D3B (5'-TCG GAA GGAACC AGC TAC TA-3') (Penas et al., 2006). The PCR products were cloned into a pDrive vector (QIAGEN), and sequenced using universal M13 primers.

All sequences were analysed and aligned using the software XBioEdit, version 7.1.11 (Hall, 1999). The tree topology was obtained by maximum likelihood analyses, with 1000 bootstrap replicates, using the MEGA v5.1 software (Tamura et al. 2007). Outgroup was chosen with regards to study of Van den Berg et al. (2014). The species names and respective National Center for Biotechnology Information (NCBI) accession number are shown in each tree.

To evaluate morphometric variability among individual populations of $P$. straeleni and to find morphometric characters accounting 
Table 1. Morphometrics of females and males Paratylenchus (Gracilacus) straeleni from Turkey and other populations from Czech Republic and Slovakia used for factor analyses. All measurements are in $\mu \mathrm{m}$ and are in the form: mean $\pm \mathrm{sd}$ (min-max)

\begin{tabular}{|c|c|c|c|c|c|c|}
\hline Locality & TR - Ordu & CZ 8 - Trí Skalky & SK - Remetské Hámre & TR - Ordu & CZ 8 - Tři Skalky & SK - Remetské Hámre \\
\hline$n$ & 13 우 & 15 우 & 17 우 & 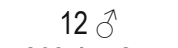 & $5 \widehat{\sigma}$ & $3 \sigma^{\lambda}$ \\
\hline L & $\begin{array}{c}353.1 \pm 23.8 \\
(311.0-383.6)\end{array}$ & $\begin{array}{c}333.2 \pm 25.7 \\
(268.1-361.7)\end{array}$ & $\begin{array}{c}314.6 \pm 20.5 \\
(278.9-352.0)\end{array}$ & $\begin{array}{c}263.1 \pm 2.7 \\
(258.3- \\
266.9)\end{array}$ & $\begin{array}{c}341.6 \pm 21.0 \\
(312.0-359.8)\end{array}$ & $\begin{array}{c}331.5 \pm 7.7 \\
(325.7-340.3)\end{array}$ \\
\hline a & $\begin{array}{c}22.5 \pm 2.4 \\
(19.0-26.4)\end{array}$ & $\begin{array}{c}23.4 \pm 1.9 \\
(18.4-26.4)\end{array}$ & $\begin{array}{c}24.5 \pm 2.0 \\
(20.4-28.3)\end{array}$ & $\begin{array}{c}29.6 \pm 1.1 \\
(28.1-31.5)\end{array}$ & $\begin{array}{c}28.6 \pm 3.1 \\
(26.4-33.5)\end{array}$ & $\begin{array}{c}29.5 \pm 1.2 \\
(28.1-30.4)\end{array}$ \\
\hline$b$ & $\begin{array}{c}3.5 \pm 0.4 \\
(3.1-4.4)\end{array}$ & $\begin{array}{c}3.3 \pm 0.2 \\
(2.9-3.5)\end{array}$ & $\begin{array}{c}3.0 \pm 0.1 \\
(2.8-3.2)\end{array}$ & - & $\begin{array}{c}3.6 \pm 0.1 \\
(3.6-3.8)\end{array}$ & $\begin{array}{c}3.3 \pm 0.1 \\
(3.2-3.4)\end{array}$ \\
\hline c & $\begin{array}{c}11.7 \pm 1.3 \\
(10.0-13.7)\end{array}$ & $\begin{array}{c}12.0 \pm 0.9 \\
(10.9-13.8)\end{array}$ & $\begin{array}{c}12.2 \pm 0.7 \\
(10.9-13.7)\end{array}$ & $\begin{array}{c}10.7 \pm 0.7 \\
(10.1-12.3)\end{array}$ & $\begin{array}{c}12.0 \pm 1.0 \\
(11.2-13.6)\end{array}$ & $\begin{array}{c}12.3 \pm 0.6 \\
(11.9-12.9)\end{array}$ \\
\hline$c^{\prime}$ & $\begin{array}{c}3.2 \pm 0.4 \\
(2.5-3.8)\end{array}$ & $\begin{array}{c}3.5 \pm 0.4 \\
(2.9-4.5)\end{array}$ & $\begin{array}{c}3.1 \pm 0.3 \\
(2.5-3.5)\end{array}$ & $\begin{array}{c}2.8 \pm 0.2 \\
(2.4-3.1)\end{array}$ & $\begin{array}{c}3.3 \pm 0.4 \\
(2.9-3.6)\end{array}$ & $\begin{array}{c}3.2 \pm 0.1 \\
(3.1-3.2)\end{array}$ \\
\hline V & $\begin{array}{c}81.5 \pm 2.8 \\
(77.2-89.9)\end{array}$ & $\begin{array}{c}81.3 \pm 1.0 \\
(79.6-83.0)\end{array}$ & $\begin{array}{c}82.0 \pm 0.8 \\
(80.9-83.2)\end{array}$ & - & - & - \\
\hline Stylet length & $\begin{array}{c}56.1 \pm 1.8 \\
(53.4-59.4)\end{array}$ & $\begin{array}{c}54.5 \pm 3.1 \\
(48.8-59.3)\end{array}$ & $\begin{array}{c}52.7 \pm 2.5 \\
(47.6-56.9)\end{array}$ & - & - & - \\
\hline Cone length & $\begin{array}{c}43.3 \pm 1.7 \\
(40.7-46.2)\end{array}$ & $\begin{array}{c}42.6 \pm 2.6 \\
(37.4-46.4)\end{array}$ & $\begin{array}{c}40.7 \pm 2.0 \\
(37.4-43.7)\end{array}$ & - & - & - \\
\hline $\mathrm{m}$ & $\begin{array}{c}77.2 \pm 1.6 \\
(75.3-81.8)\end{array}$ & $\begin{array}{c}78.1 \pm 1.4 \\
(75.6-82.2)\end{array}$ & $\begin{array}{c}77.3 \pm 1.1 \\
(74.8-78.7)\end{array}$ & - & - & - \\
\hline EP & $\begin{array}{c}85.6 \pm 6.9 \\
(72.1-96.5)\end{array}$ & $\begin{array}{c}77.3 \pm 4.6 \\
(68.8-83.1)\end{array}$ & $\begin{array}{c}77.9 \pm 4.0 \\
(71.8-86.6)\end{array}$ & $\begin{array}{c}60.9 \pm 3.4 \\
(55.5-66.2)\end{array}$ & $\begin{array}{c}75.7 \pm 3.4 \\
(71.0-79.6)\end{array}$ & $\begin{array}{c}74.4 \pm 1.2 \\
(73.3-75.7)\end{array}$ \\
\hline EP\%L & $\begin{array}{c}24.3 \pm 1.5 \\
(22.3-27.5)\end{array}$ & $\begin{array}{c}23.3 \pm 1.1 \\
(21.6-25.7)\end{array}$ & $\begin{array}{c}24.8 \pm 1.1 \\
(22.8-26.7)\end{array}$ & $\begin{array}{c}23.1 \pm \\
(21.5-24.8)\end{array}$ & $\begin{array}{c}22.2 \pm 0.8 \\
(21.2-23.1)\end{array}$ & $\begin{array}{c}22.4 \pm 0.7 \\
(21.8-23.2)\end{array}$ \\
\hline Tail lenght & $\begin{array}{c}30.3 \pm 2.2 \\
(26.8-34.2)\end{array}$ & $\begin{array}{c}27.8 \pm 3.0 \\
(23.4-33.2)\end{array}$ & $\begin{array}{c}25.8 \pm 2.2 \\
(21.5-29.3)\end{array}$ & $\begin{array}{c}24.7 \pm 1.5 \\
(23.7-26.1)\end{array}$ & $\begin{array}{c}28.5 \pm 2.2 \\
(26.3-32.2)\end{array}$ & $\begin{array}{c}27.0 \pm 0.6 \\
(26.3-27.3)\end{array}$ \\
\hline Pharynx length & $\begin{array}{c}100.6 \pm 12.1 \\
(78.4-121.0)\end{array}$ & $\begin{array}{c}101.0 \pm 5.4 \\
(91.7-110.2)\end{array}$ & $\begin{array}{c}106.1 \pm 3.6 \\
(100.4-112.1)\end{array}$ & - & $\begin{array}{c}93.8 \pm 4.2 \\
(87.8-97.5)\end{array}$ & $\begin{array}{c}100.1 \pm 6.3 \\
(95.6-107.3)\end{array}$ \\
\hline Spicula & - & - & - & $\begin{array}{c}15.3 \pm 1.1 \\
(13.0-16.9)\end{array}$ & $\begin{array}{c}19.6 \pm 1.1 \\
(18.7-21.5)\end{array}$ & $\begin{array}{c}18.6 \pm 1.0 \\
(17.6-19.5)\end{array}$ \\
\hline Gubernaculum & - & - & - & - & $\begin{array}{c}4.7 \pm 0.3 \\
(4.3-5.1)\end{array}$ & $\begin{array}{c}3.9 \pm 0.5 \\
(3.4-4.3)\end{array}$ \\
\hline
\end{tabular}

$\mathrm{n}=$ number of nematodes; $\mathrm{EP}=$ the distance from anterior end of body to the excretory pore; $\mathrm{EP} \% \mathrm{~L}=$ position of excretory pore in percent of body length; $\mathrm{m}=$ stylet cone length expressed in percentage of total stylet length

for majority of species variability Factor Analysis was conducted. The Factor Analysis was based on mean values of morphometric characters for females of populations that were measured in the present study - populations (Table 2): TR (Ordu - Turkey), CZ8 (Křivoklátsko, Tři Skalky, Czech Republic) and SK (Vihorlat, Remetské Hámre, Slovakia). Details on the locality of CZ8 P. straeleni population were published by Háněl $(1996,2009)$ and details on the locality of SK $P$. straeleni population are in paper by Háněl \& Čerevková (2010). Biometrical data on other populations were taken from previously published studies - populations: CZ1-6 (Brzeski \& Háněl, 2000), CZ7 (Brzeski \& Háněl, 1999), E (Castillo \& Gomez-Barcina, 1988). PL1-5 and I (Brzeski, 1995), ZA (Van den Berg \& Tiedt 2001), USA1 (Van den Berg et al. 2014),
USA2 (Tarjan, 1960 - P. sarissus), USA3 (Raski, 1962 - P. sarissus) R01,2 (Ciobanu et al., 2003), DK (Raski, 1976), CDN (Brown, 1959 - Paratylenchus andrilellus), B1 (De Coninck, 1931 - type specimens of $P$. straeleni), B2 (Geraert, 1965 - neotype of $P$. straeleni), RUS1 and RUS2 (Eroshenko, 1974 - P. abietis, type female and paratype females, respectively). If any value of certain morphometric character was missing in the published descriptions, a mean value of that character across all populations was used. The factor analysis produced a set of variables (factors) that were linear combinations of the original variables. The new variables (factors) were independent of each other and ranked according to the amount of variation accounted for. After the initial factor extraction by the principal component method, an orthogonal varimax 
raw rotation was used to estimate the factor loadings. Only factors with an eigenvalue greater than 1 were extracted. All analyses were performed using Statistica, version 10 (StatSoft Inc., 2013).

\section{Results}

Description of Paratylenchus (Gracilacus) straeleni associated with the roots of hazelnuts

Female: Measurements see Table 1. Body ventrally arcuate, more so in posterior and narrows anterior to vulva for mature females (Fig. 2). Lateral field with four lines in all females examined. Head continuous with body contour, conical, rounded to truncate. Stylet strongly developed, mostly arcuate with rounded knobs. Valve plates in median bulb well developed. EP situated opposite to the mid-point of isthmus. Pharynx well developed. Spermatheca mostly filled with sperm, rounded to slightly oval in shape. Vulva with distinct lateral vulval flap. Tail tapering with conical pointed to slightly rounded tail tip.

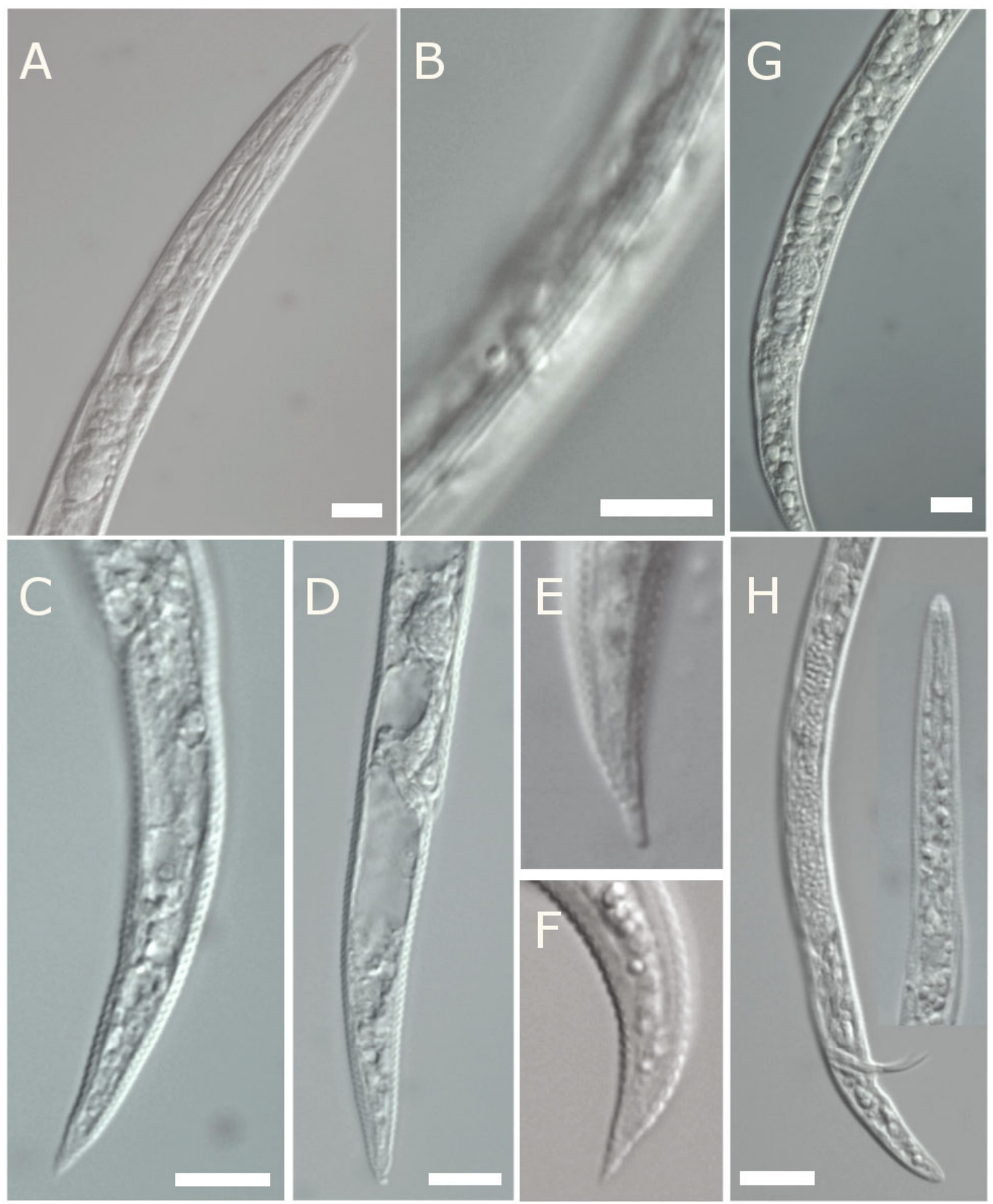

Fig. 2. Light micrographs of Paratylenchus (Gracilacus) straeleni, Turkey population KM875547: A - anterior part of body, (stylet, median bulb and pharynx); B - lateral field at mid-body (incisure); C, D - posterior part of female body; E, F - tail tip of female; G - female gonad, H - posterior and anterior part of male body (Spiculae, sperm in seminal vesicle, excretory pore) (scale bare $=10 \mu \mathrm{m})$ 
Table 2. Eigenvector and eigenvalues of Factor Analysis derived from nematode morphometric characteristics for populations of Paratylenchus (Gracilacus) straeleni from different locations all over the world

\begin{tabular}{lcccc}
\hline & Factor 1 & Factor 2 & Factor 3 & Factor 4 \\
\hline $\mathrm{L}$ & $\mathbf{0 . 7 3 7}$ & 0.244 & 0.454 & 0.175 \\
$\mathrm{a}$ & -0.093 & -0.148 & 0.172 & $\mathbf{0 . 8 1 7}$ \\
$\mathrm{b}$ & $\mathbf{0 . 6 7 5}$ & 0.137 & -0.008 & -0.143 \\
$\mathrm{C}$ & 0.070 & $\mathbf{0 . 8 7 9}$ & -0.063 & -0.169 \\
$\mathrm{C}^{\prime}$ & 0.069 & -0.629 & -0.148 & 0.444 \\
$\mathrm{~V}$ & 0.165 & $\mathbf{0 . 7 0 8}$ & 0.162 & 0.416 \\
Stylet length & 0.292 & -0.543 & 0.303 & 0.204 \\
Cone length & 0.536 & -0.496 & -0.392 & 0.107 \\
$\mathrm{~m}$ & 0.210 & 0.236 & -0.678 & -0.264 \\
EP & 0.453 & 0.030 & $\mathbf{0 . 7 4 4}$ & 0.014 \\
EP\%L & -0.567 & 0.009 & 0.062 & -0.552 \\
Tail lenght & $\mathbf{0 . 7 6 3}$ & -0.152 & 0.205 & -0.140 \\
Pharynx length & 0.129 & 0.100 & $\mathbf{0 . 8 8 3}$ & 0.025 \\
\hline Eigenvalues & 2.59 & 2.40 & 2.37 & 1.57 \\
\% of total variance & 19.90 & 18.47 & 18.24 & 12.04 \\
Cumulative \% of total & 19.90 & 38.37 & 56.62 & 68.66 \\
variance & Values of morphometric and morphological characters dominating factors 1 to 4 \\
(eigenvector $>0.6$ ) are highlighted in bold & & & \\
\hline
\end{tabular}

Male: Measurements see Table 1. Body slightly arcuate. Lateral field with 4 lines in males examined. Head continuous with body contour, rounded (Fig. 2). Stylet not visible. Pharynx degenerate and probably non-functional. EP located at the isthmus level. Tail short from bluntly rounded to conoid, almost pointed tail tip. Spicules thin, curved ventrally. Sperms numerous.

\section{Multivariate analyses}

The analyses were based on mean values of morphometric characters of 29 populations of $P$. straeleni from different parts of the world (Fig. 1) included in Table 1 or published previously by various authors listed in material and methods. The first four factors (eigenvalue $>1.5$ ) accounted for $68.66 \%$ of the total variance of morphometric characters of the populations included in the analyses. Table 2 includes the eigenvalues for the four factors extracted, which were a combination of all characters in the analysis, and the corresponding values in the eigenvectors for each character that were used to interpret the significance of the factors. Factor 1 is dominated by high positive weights (eigenvector $>0.67$ ) for body $(\mathrm{L})$, tail length and ratio $\mathrm{b}$ (Tab 2; Fig. 3). Factor 2 is dominated by high positive weights (eigenvector $>0.70$ ) for ratios $V$ and $c$ and high negative value (eigenvector $=-0.63$ ) for ratio c' $($ Tab 2; Fig. 3). Factor 3 is dominated by high positive weights (eigenvector $>$ 0.74) for distance of EP from anterior end of body and pharynx length and by high negative value (eigenvector $=-0.68$ ) for ratio $\mathrm{m}$ (Table 2) and factor 4 only by high positive weight (eigenvector = 0.82 ) for ratio a (Table 2).

The remaining morphometric characters are not highly associated (eigenvector $<0.60$ ) with any of the four factors. EP \%L (eigenvec-

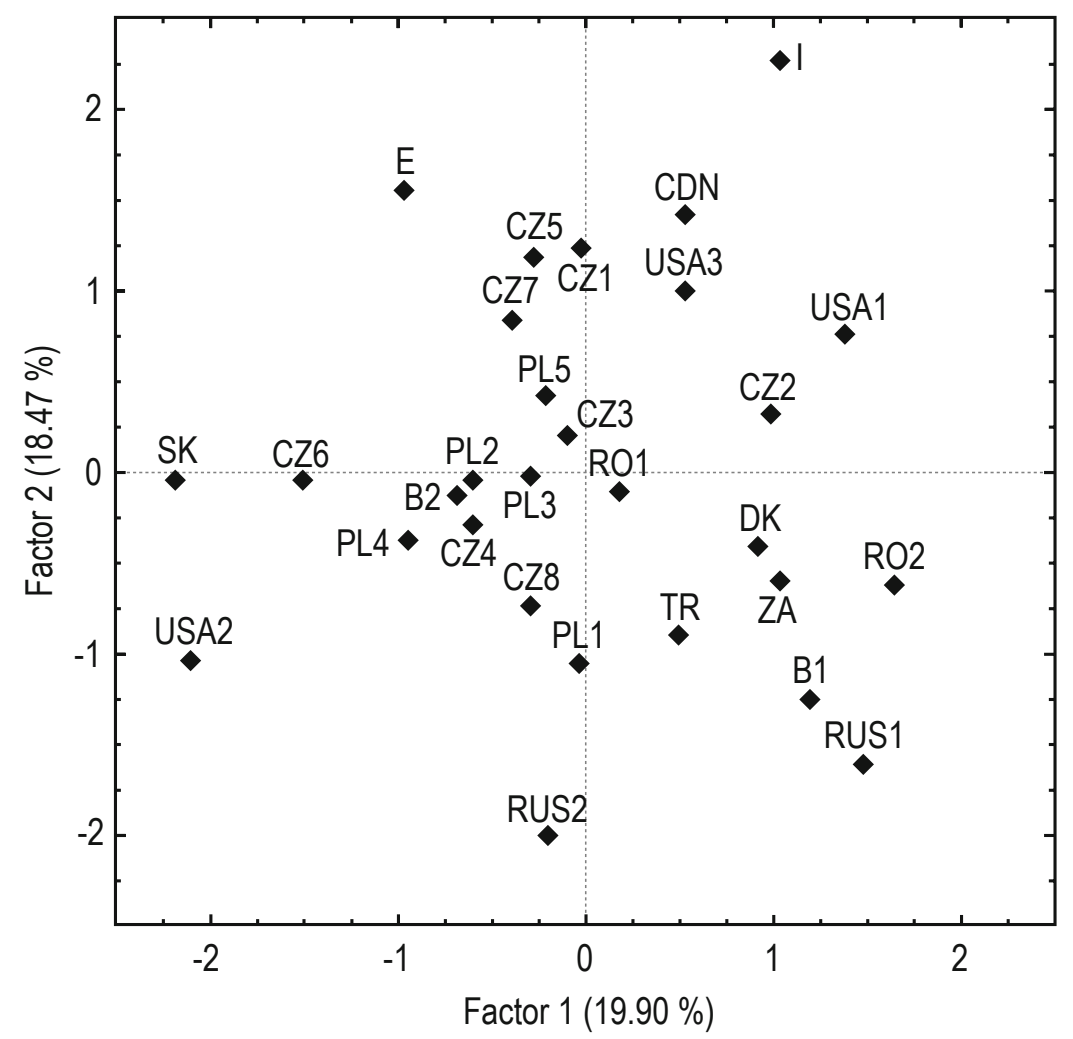

Fig. 3. Factor Analyses of different morphometric characteristics of 29 populations of Paratylenchus (Gracilacus) straeleni 
tor $=-0.57$ ), cone (eigenvector $=0.54$ ) and stylet length (eigenvector $=-0.54$ ) were associated with factor 1 and 2 respectively. Analysed populations of $P$. straeleni are projected on the plane of factors 1 and 2 in Cartesian plots (Fig. 3).

Factor 1 is presented graphically as $x$-axis and factor 2 as $y$-axis. The populations are located along full length of these axes, which indicates a wide range of variation of all morphometric characters associated with either factor. The majority of analysed populations from Central Europe together with neotype population (B2) of $P$. straeleni are concentrated in the middle of the plots. Type population of $P$. straeleni (B1) is located in the middle of the lower right quadrant close to the type female of $P$. abietis (RUS1). The paratype population of $P$. abietis (RUS2) is located in the lower part of the axis $\mathrm{y}$ and is therefore characterised by a low value of the ratio $\mathrm{V}$.

As concerns $P$. sarissus, population USA3 was associated with greater values of $C$ and $V$ and therefore located together with a population of $P$. straeleni from USA (USA1), a population of $P$. audriellus from Canada (CDN) and a population of $P$. straeleni from the Czech Republic (CZ1). The second population of $P$. sarissus (USA2) is characterised by lower values of body length (L) and tail length and is therefore located on the left side of the diagram together with small females of $P$. straeleni in Slovakia SK. $P$. straeleni from Turkey (TR) belongs into the group of populations of this species characterised by relatively low values of body length $(\mathrm{L})$ and ratio $\mathrm{c}$ and therefore it is located in the right lower quadrant between populations PL1 and B1-ZA-DK.

\section{Phylogenetic relationship}

The D2-D3 of 28S rRNA gene sequence alignment was $731 \mathrm{bp}$ in length. Phylogenetic relationships between species are given in Figure 4. Basiria gracilis and Aphelenchus avenae were chosen as outgroup taxa. Two major clades were distinguished in a constructed tree (Fig. 4). Clade I included P. nanus, P. hamatus,
P. bukowinensis, P. dianthus, P. straeleni and Paratylenchus sp. 8. Clade II solely consisted of $P$. aquaticus. A population from Turkey (KM875547) is included in Clade I and is closely related to Paratylenchus sp. 8 (KF242234 and 33) and P. straeleni (KF242236 and 35) from the USA.

\section{Discussion}

Paratylenchus straeleni s.l. is world-wide distributed species but is mainly restricted to temperate and Mediterranean climates (Fig. 1). However, the species shows a high degree of variability in morphological, morphometrical and molecular characteristics. Populations subjected to Factor Analysis in our study are scatted across all quadrants delimited by Factor 1 and Factor 2 axes. The first three Factors had similar eigenvalues, possibly indicating that variation in morphometric characteristics resulted from a number of internal (genetical) and external (environmental) variables. Great variation in body length; tail length; and ratios b, $c$ and $c$ ' is not a surprise. But, a relatively high degree of variation in the vulva position contrasts with results of study by Brzeski \& Háněl (2000) and Ghaderi et al. (2014) who found vulva position as the most stable characteristic. On the other hand, in accordance with their studies, the stylet and the cone length showed low variation across the populations compared in the present study.

Surprisingly, a low degree of variation was also found in the EP \%L index. Stability of the position of excretory (or secretory-excretory) pore is problematic and rather variable across various groups of species, from about 18 to $28 \%$ body length (Raski 1962, Siddiqi \& Goodeyi 1964, Brzeski 1998). For individual closely related groups of species this index may be taken as a reliable diagnostic character. For example, Brzeski (1995) found that the mean values of EP \%L index varied from 24.1 to $25.2 \%$ in Gracilacus straeleni s.l. In short-stylet species such as Paratylenchus similis and Paraty-

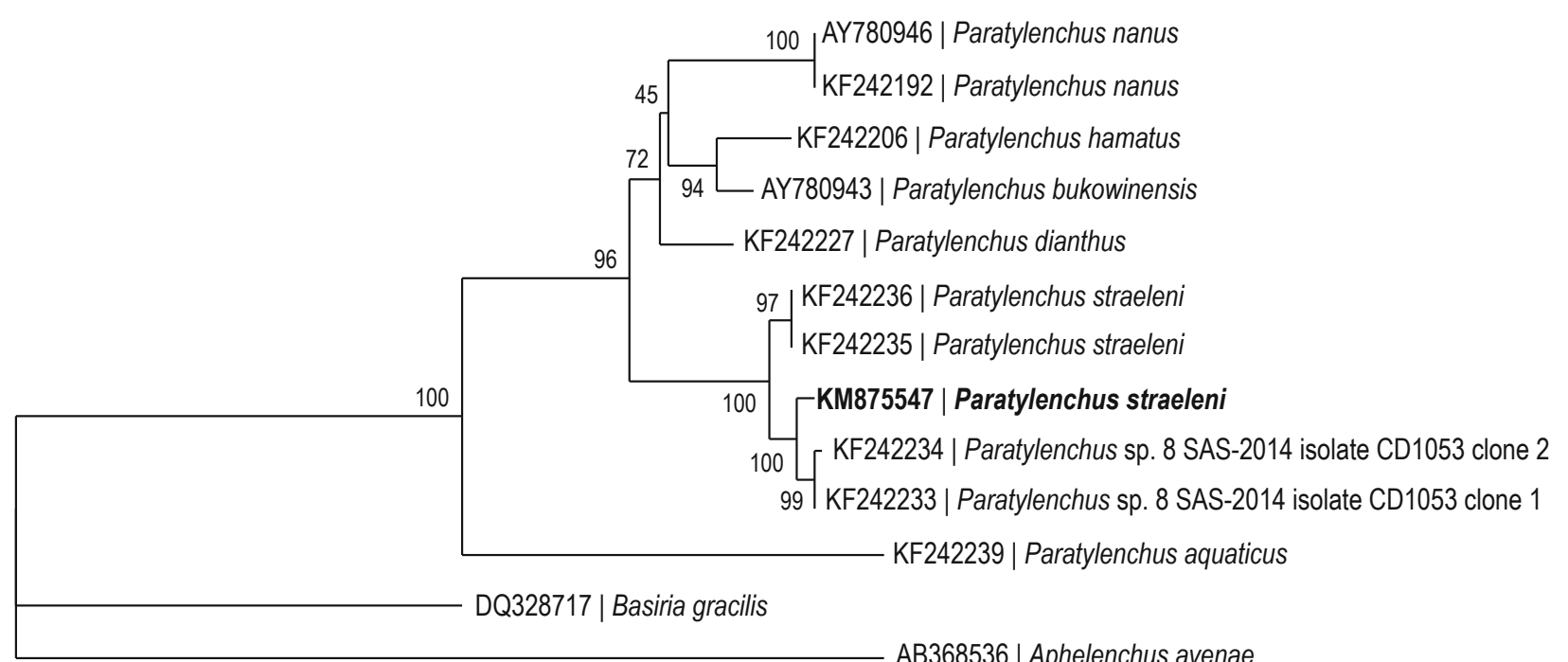

AB368536 | Aphelenchus avenae

Fig. 4. Phylogenetic relationships between representatives of the genus Paratylenchus in sensu Siddiqi (2000): Bayesian 50\% majority consensus tree for the D2-D3 of $28 \mathrm{~S}$ rRNA gene sequence alignment. Numbers at nodes are posterior probabilities values. Original sequence is indicated by bold font 
Oostenbrink (1960)

Paratylenchus Micoletzky, 1922

Paratylenchus audriellus Brown, 1959

Paratylenchus straeleni (de Coninck, 1931) n. comb. syn. Hemicycliophora straeleni (de Coninck, 1931) Loos, 1948

Paratylenchus strenzkei (Volz, 1951) n. comb. syn. Hemicycliophora strenzkei Volz, 1951

Raski (1962):

Gracilacus Raski, 1962

Gracilacus audriellus (Brown, 1959) n. comb. syn. Paratylenchus audriellus Brown, 1959

Gracilacus sarissus (Tarjan, 1960) n. comb. syn. Paratylenchus sarissus Tarjan, 1960

Geraert (1965):

Paratylenchus Micoletzky, 1922

Paratylenchus straeleni (De Coninck, 1931) Oostenbrink, 1960 syn. Paratylenchus sarissus Tarjan, 1960 syn. ? Hemicycliophora (= Procriconema) strenzkei Volz, 1951 syn. ? Paratylenchus strenzkei (Volz, 1951) Oostenbrink, 1960 Paratylenchus audriellus Brown, 1959

Raski (1976)

Gracilacus Raski, 1962

Gracilacus straeleni (de Coninck, 1931) n. comb. syn. Procriconema straeleni de Coninck, 1931 syn. Paratylenchus straeleni (de Coninck, 1931) Oostenbrink, 1960 syn. Paratylenchus sarissus Tarjan, 1960 syn. n. Paratylenchus audriellus Brown, 1959 Gracilacus abietis (Eroshenko, 1974) n. comb. syn. Paratylenchus abietis Eroshenko, 1974

Species inquirenda: Paratylenchus strenzkei (Volz, 1951) Oostenbrink, 1960 syn. Hemicycliophora (= Procriconema) strenzkei Volz, 1951

Brzeski (1998)

Paratylenchus Micoletzky, 1922

Paratylenchus straeleni (de Coninck, 1931) Ooostenbrink, 1960 syn. Paratylenchus audriellus Brown, 1959 syn. Paratylenchus sarissus Tarjan, 1960 syn. n. Paratylenchus abietis Eroshenko, 1974

Siddiqi (2000):

Paratylenchus Micoletzky, 1922; subgenus Gracilacus Raski, 1962 (Siddiqi, 1986)

Paratylenchus (Gracilacus) abietis Eroshenko, 1974 syn. Paratylenchus abietis Eroshenko, 1974 (syn. of P. straeleni for Brzeski, 1998) syn. Gracilacus abietis (Eroshenko, 1974) Raski, 1976

Paratylenchus (Gracilacus) straeleni (de Coninck, 1931) Oostenbrink, 1960

syn. Procriconema straeleni de Coninck, 1931 syn. Hemicycliophora straeleni (de Coninck, 1931) Loos, 1948 syn. Paratylenchus straeleni (de Coninck, 1931) Oostenbrink, 1960 syn. Gracilacus straeleni (de Coninck, 1931) Raski, 1976 syn. Paratylenchus audriellae Brown, 1959 syn. Gracilacus audriellae (Brown, 1959) Raski, 1962 syn. Paratylenchus sarissa Tarjan, 1960 syn. Gracilacus sarissa (Tarjan, 1960) Raski, 1962 


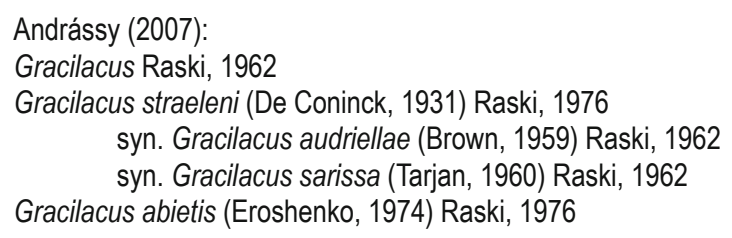

Ghaderi et al. (2014):

Paratylenchus Micoletzky, 1922 sensu lato

Paratylenchus straeleni (De Coninck, 1931) Oostenbrink, 1960

syn. Paratylenchus abietis Eroshenko, 1974 (valid species for Siddiqi (2000) and Andrásssy (2007)) syn. Paratylenchus audriellus Brown, 1959

syn. Paratylenchus sarissus Tarjan, 1960

syn. Gracilacus abietis (Eroshenko, 1974) Raski, 1976

syn. Gracilacus audriellae (Brownm 1959) Raski, 1962

syn. Gracilacus sarissa (Tarjan, 1960) Raski, 1962

syn. Gracilacus straeleni (de Coninck, 1931) Raski, 1976

syn. Procriconema straeleni de Coninck, 1931

syn. Hemicycliophora straeleni (de Coninck, 1931) Loos, 1948

Species inquirenda: Paratylenchus strenzkei (Volz, 1951) Oostenbrink, 1960 (by Raski

(1976); syn. of Paratylenchus strealeni for Geraert (1965))

lenchus microdorus varied from 19.0 to $23.7 \%$ and from 20.0 to $22.4 \%$, respectively. Most recently, Ghaderi et al. (2014) surveyed Paratylenchus s.l. and concluded that V, $\mathrm{m}, \mathrm{EP} \% \mathrm{~L}$, and stylet had the smaller coefficients of variation. Position of excretory pore and its usefulness for species descriptions should be therefore paid further investigation.

Relatively high variation of the $\mathrm{V}$ index along the Factor 1 left paratype population of Paratylenchus abietis (RUS2) in position separate from other populations (Fig. 3). The holotype female of this species was located closely to the type population of Paratylenchus straeleni B1. This suggest that Paratylenchus abietis can be synonymized with Paratylenchus (Gracilacus) straeleni as done by Brzeski (1998) and confirmed by Ghaderi et al. (2014)

The description of Paratylenchus abietis was based upon a smooth head, swelled posterior part of the pharynx corpus, anterior position of hemizonid relative to excretory pore (Eroshenko 1974). The range of values in the index $V$ was wider in paratypes $(76-82 \%)$ than in type population and neotype of Paratylenchus straeleni (80 - 82 \%) (Geraert 1965). Raski (1976) considered Gracilacus abietis a distinct species due to greater anterior $\mathrm{V}$ values than in the composite values ( $V=79-85 \%$ ) for all populations of Gracilacus straeleni reported in his paper. Hemizonid position in populations studied by Brzeski \& Háněl, $(1999,2000)$ as well as CZ8 and SK varied from anterior to posterior relative to the excretory pore. Brzeski (1998) synonymized $P$. abietis with $P$. straeleni by rejecting the proposed differences as invalid for species differentiation: striae on head are not clearly visible enough in most females to be a reliable character, the position of EP is variable within all Paratylenchus species examined and the vulva positions show large overlap. However, the synonymization should be validated by careful molecular comparison as strongly recommended by Van den Berg et al. (2014).

The positions of two examined populations of $P$. sarissus (USA2 and USA3) in our factor analysis were divergent. Holotype of $P$. sarissus marked as USA2 was placed in the lower left part of the diagram because of strong influence of characters body length $(L)$ and tail length. However, the second examined population of $P$. sarissus (USA3), characterized by higher values of body length (L) and ratios $\mathrm{C}$ and $\mathrm{V}$ was located in the upper right part of the $\mathrm{y}$-axis close to $P$. audriellus (CDN) and the populations of $P$. straeleni from USA (USA1) and the Czech Republic (CZ1). The location of those populations together shows low variability in the general diagnostics characters mentioned in their descriptions and indicates validity in their synonymizations with $P$. straeleni.

The population of Paratylenchus straeleni from Turkey (TR) was placed in the lower left quadrant of the diagram (Fig. 3) occupied by some populations of the species from Europe and Asia. Females of the TR population thus fall within the range of variation of morphometric characters in other populations. However, the spicules of TR males were somewhat shorter than those in a number of others (DK, CZ7, CZ8, SK, RUS2, USA2, USA3, CND). This may suggest that the TR population represents a subspecies or crypic (sibling) species within Paratylenchus strealeni s.l.

Variation in different characters can result from different causes. Total body length can be influenced by available food. Therefore, differences in $L$ and tail length along the Factor 1 axis may reflect environmental factors rather than taxonomic difference. The values of the ratio $b$ are product of body length and pharynx length. Pharynx length varied along the Factor 3 axis and, as the stylet length showed little variation, the pharynx likely should be less variable than the total body length in order to operate the stylet movement effectively. Moreover, low variation in stylet length strongly suggests that this structure is genetically determined.

The vulval positions that varied along the Factor 2 axis can be differentiated genetically rather than environmentally as low variation in the index $V$ was established by Brzeski \& Háněl (2000) and Ghaderi et al. (2014). Thus, Paratylenchus abietis could be regarded as a subspecies or a cryptic species within a wide range of populations of Paratylenchus straeleni s.l. across the world and Andrássy (2007) still keep P. abietis as a valid species in accord 
with Raski (1976). As mentioned above, genetic studies could be very valuable to fix such issues (Van den Berg et al. 2014).

Our study also showed that different populations of Paratylenchus straeleni s.l. differ genetically (Fig. 4), at least in those nucleotide sequences that are detectable with relatively routine procedures. As concerns separation of (sub)genera Paratylenchus and Gracilacus (and possibly more), Van den Berg et al. (2014) concluded that the validity of Gracilacus cannot be rejected using available gene datasets. Furthermore, they concluded that the question of validity of genus Gracilacus based only on the fact of stylet length $48 \mu \mathrm{m}$ and greater (introduced by Raski, 1962) is still unresolved. The data established by Brzeski \& Háněl (2000) showed that the elongation of the stylet is mainly due to the elongation of the cone. Finding genes responsible for stylet elongation in Paratylenchus-Gracilacus populations could prompt more convincing arguments for recognition/rejection of the validity of the genus Gracilacus than one based on rDNA segments that also vary in species that bear no stylet. Ghaderi et al. (2014) provided a list of 117 valid species of Paratylenchus s.I. together with a dichotomous identification key and a diagnostic compendium. Our study documented that in even one species recognized as valid rest many questions to be answered. Because the genus is comprised of plant-parasitic species and because some can be important pests to agricultural crops (Oostenbrink 1960, Evans et al. 1993, Brzeski 1998, Siddiqi 2000, Andrássy 2007, Sturhan 2014), further research on taxonomy, biology and ecology is therefore required.

\section{Acknowledgements}

We would like to thank to P. Vieira for his advices about molecular phylogeny and to C. Kirkman for his assistance with English review. This research was partly supported by European Social Fund and the state budget of the Czech Republic, Project Indicators of trees vitality Reg. No. CZ.1.07/2.3.00/20.0265 (Čermák, Foit).

\section{References}

Akyazı, F., Yıldiz, S., Felek, A. F. (2014): Soil nematode communities associated with hazelnut orchards in Turkey. J. Entomol. Nematol., 6(8): 112 - 121. DOI: 10.5897/JEN2014.0104 ANDRÁsSY, I. (2007): Free-living nematodes of Hungary (Nematoda errantia) Volume II., Hungarian Natural History Museum and Systematic Zoology Research Group of the Hungarian Academy of Sciences, Budapest, Hungary, $496 \mathrm{pp}$.

BRown, G. L. (1959): Three new species of the genus Paratylenchus from Canada (Nematoda: Criconematidae). Proc. Helminthol. Soc. Wash., 26(1): $1-8$.

BRZESKI, M.W. (1995): Paratylenchinae: morphology of some known species and descriptions of Gracilacus bilineata sp. n. and G. vera sp. n. (Nematoda: Tylenchulidae). Nematologica, 41: 535 - 565. DOI: 10.1163/003925995X00495.

BrzesKI, M.W. (1998): Nematodes of Tylenchina in Poland and temperate Europe. Muzeum i Institut Zoologii Polska Akademia Nauk, Warszawa. 397 pp.

BRZESKI, M.W. , HÁNĚL, L. (1999): Paratylenchinae: postembryon- ic developmental stages of Paratylenchus straeleni (De Coninck, 1931) abd P. steineri Golden, 1961 (Nematoda: Tylenchulidae). Nematology, 1(7 - 8): 673 - 680. DOI: 10.1163/156854199508630 BRZESKI, M.W., HÁněL, L. (2000): Paratylenchinae: evaluation of diagnostic morho-biometrical characters of females in the genus Paratylenchus Mikoletzky, 1922 (Nematoda: Tylenchulidae). Nematology, 2(3): 253 - 261. DOI: 10.1163/156854100509097

Castillo, P., Gomez-Barcina, A. (1988): Some species of Tylenchida from natural habitats in southern Spain. Nematol. Mediterr., 16 : $75-86$

Ciobanu, M., Geraert, E., Popovici, I. (2003): The genera Paratylenchus Micoletzky, 1922 and Gracilacus Raski, 1962 in Romania (Nematoda: Tylenchulidae). Nematol. Mediterr., 31: 51 - 59

Cовв, N.A. (1918). Estimating the nema population of the soil, with special reference to the sugar-beet and root-gall nemas, Heterodera schachtii Schmidt and Heterodera radicicola (Greef) Muller, and with a description of Tylencholaimus aequalis n. sp. Agric. Techn. Circ. US Dep. Agric., 1: 1 - 47

De Coninck, L.A.P. (1931): Sur trois espèces nouvelles des nématodes libres trouvés en Belgique. Bull. Mus. roy. Hist. natur. Belg., 7(11): 1 - 15

De GrISSE, A. (1969): Redescription ou modifications de quelques techniques utilisées dans l'étude des nématodes phytoparasitaires. Meded. Rijksfac. Landb.-Wet. Gent, 34: 351 - 369

EROSHENKo, A.S. (1974): A new species of nematodes from coniferous forests in the Far East of the USSR. Parazitologiya, 8(3): 220 - 222 (In Russian)

Evans, K., Trudgill D.L., Webster J.M. (Eds) (1993): Plant Parasitic Nematodes in Temperate Agriculture. CAB INTERNATIONAL, Wallingford, UK: $648 \mathrm{pp}$.

Ghaderi, R., Kashi, L., Karegar, A. (2014): Contribution to the study of the genus Paratylenchus Micoletzky, 1922 sensu lato (Nematoda: Tylenchulidae). Zootaxa, 3841(2): 151 - 187. DOI: 10.11646/ zootaxa.3841.2.1

Geraert, E. (1965): The genus Paratylenchus. Nematologica, 11(3): $301-334$

HALL, T.A. (1999): BioEdit: a user-friendly biological sequence alignment editor and analysis program for Windows 95/98/NT. Nucleic Acids Symp. Ser., 41: 95 - 98

HÁNĚL, L. (1996): Soil nematodes (Nematoda) in forest ecosystems of the Krivoklátsko Biosphere Reserve, Czech Republic. J. Nat. Mus. Ser. Nat. Sci. , 165(1 - 4): 91 - 102

HáNĚL, L. (2009): Soil nematodes in ungulate grazed and ungrazed forests of the Krivoklátsko Biosphere Reserve - first results of an ongoing project. In: TAJovskÝ, K., SchlaghamerskÝ, J., PIŽL, V. (Eds) Contributions to Soil Zoology in Central Europe III. České Budějovice, ISB BC AS CR, v.v.i., 47 - 51 (191 pp.)

HÁnĚL, L., ČEREVkovÁ, A. (2010): Species and genera of soil nematodes in forest ecosystems of the Vihorlat Protected Landscape Area, Slovakia. Helminthologia, 47(2): 123 - 135. DOI: 10.2478/ s11687-010-0019-6

KePENEKCI, I. (2002): A survey of Tylenchida (Nematoda) found in hazelnut (Corylussp.) orchards in the west Black Sea Region of Turkey. Nematropica, 32, $83-85$

Kyrou, N.C. (1976): New records of nematodes in Greece. Plant Dis. Rep., 60(7): 630. 
Mancini, G., Moretti, F., Palenzona, M. (1975): Gracilacus audrie/Ius Brown: possibile agente del "seccume" del nocciolo "Gentile delle Langhe". Redia 56: 447 - 454

OostenbrinK, M. (1960): Chapter 17. The family Criconematidae. In: Sasser, J. N. \& Jenkins, W. R. (Eds.): Nematology. Fundamentals and Recent Advances with Emphasis on Plant Parasitic and Soil Forms. Chapel Hill, The University of North Carolina Press, pp. $196-205$

Penas, A.C., Metge, K., Mota, M., Valadas, V. (2006): Bursaphelenchus antoniae sp. n. (Nematoda: Parasitaphelenchidae) associated with Hylobius sp. from Pinus pinaster in Portugal. Nematology, 8: 659 - 669. DOI: 10.1163/156854106778877947

RASKI, D.J. (1962): Paratylenchidae n. fam. with descriptions of five new species of Gracilacus n. g. and an emendation of Cacoparus Thorne, 1943, Paratylenchus Micoletzky, 1922 and Criconematidae Thorne, 1943. Proc. Helminthol. Soc. Wash., 29(2): 189 - 207 RASKI, D.J, (1976): Revision of the genus Paratylenchus Micoletzky, 1922 and descriptions of new species. Part III of three parts - Gracilacus. J. Nematol., 8(2): 97 - 115

SIDDIQI, M. R., GOODEY, J. B. (1964): The status of the genera and subfamilies of the Criconematidae (Nematoda); with a comment on the position of Fergusobia. Nematologica, 9: $363-377$

SIDDIQI, M. R. (2000): Tylenchida. Parasites of Plants and Insects. $2^{\text {nd }}$ Edition, Wallingford, UK, CABI Publishing, $833 \mathrm{pp}$.
StatSOFt, Inc (2013): Electronic Statistics Textbook. StatSoft [WWW document]. URL http://www.statsoft.com/textbook/stathome.html [accessed 1 December 2013], [Computer Software]. Tulsa, Oklahoma.

StURHAN, D. (2014): Plant-parasitic nematodes in Germany - an annotated checklist. Soil Org., 86(3): 177 - 198

Tamura, K., Dudley, J., Nel, M., Kumar, S. (2007): MEGA4: Molecular evolutionary genetics analysis (MEGA) software version 4.0. Mol. Biol. Evol., 24: 1596 - 1599. DOi: 10.1093/molbev/msm092 TARJAN, A.C. (1960): A review of the genus Paratylenchus Micoletzky, 1962 (Paratylenchinae: Nematoda) with a description of two new species. Ann. N. Y. Acad. Sci., 84: $329-390$

VAn den Berg, E., Tiedt, L.R. (2001): New records of Criconemoidea (Nematoda) from South Africa, with the description of Criconema zantene n. sp. Nematology, 3(8): 797 - 815. DOI: 10.1163/156854101753625308

Van den Berg, E., Tiedt, L.R., Subbotin, A.S. (2014): Morphological and molecular characterisation of several Paratylenchus Micoletzky, 1922 (Tylenchida: Paratylenchidae) species from South Africa and USA, together with some taxonomic notes. Nematology, 16: 323 - 358. DOI:10.1163/15685411-00002769

Volz, P. (1951): Untersuchungen über die Mikrofauna des Waldbodens. Zool. Jb. Abt. Syst., 79(5/6): 514 - 566 